\title{
Wastewater effluents affect ecosystem metabolism: an evaluation of activation energy case study from the River Wandle, UK
}

Meng Zhang ( $\sim$ meng.zhang@kcl.ac.uk)

King's College London - Strand Campus: King's College London https://orcid.org/0000-0002-62184074

Michael A. Chadwick

King's College London - Strand Campus: King's College London

\section{Research Article}

Keywords: gross primary production, ecosystem respiration, activation energy, wastewater, River Wandle

Posted Date: March 1st, 2022

DOI: https://doi.org/10.21203/rs.3.rs-1366677/v1

License: (c) (i) This work is licensed under a Creative Commons Attribution 4.0 International License.

Read Full License 
1 Wastewater effluents affect ecosystem metabolism: an evaluation of

2 activation energy case study from the River Wandle, UK

3

$4 \quad$ Meng Zhang* and Michael A. Chadwick

5 Department of Geography, King's College London, UK

$6 \quad *$ corresponding author: meng.zhang@kcl.ac.uk

7 ORCID: Meng Zhang (0000-0002-6218-4074); Michael A Chadwick (0000-0003-4891-4357) 


\section{Abstract}

9 River ecosystem metabolism (REM) is a measure of ecological function which integrates gross primary

10 production (GPP) and ecosystem respiration (ER). Urban rivers often receive effluents from wastewater treatment

11 plants (WWTP) which frequently alter nutrient concentrations and modify temperature regimes of receiving water

12 bodies. In this study, we applied the nighttime slope method (NSM) to estimate diurnal REM at sites above and

13 below a wastewater outfall on the River Wandle, a tributary to the River Thames, and structural equation

14 modelling (SEM) revealed that nutrient supply, water temperature and light availability were the main factors

15 driving REM. Overall estimated GPP and ER from our study sites were like those of urban impacted rivers in

16 other countries. Upstream to downstream, GPP values $\left(0 \sim 21.2 \mathrm{mgO}_{2} \cdot \mathrm{L}^{-1} \cdot \mathrm{d}^{-1}\right)$ were similar, but ER values $(5.5 \sim$

$\left.17 \quad 10.1 \mathrm{mgO}_{2} \cdot \mathrm{L}^{-1} \cdot \mathrm{d}^{-1}\right)$ were significantly higher at the downstream site receiving WWTP effluents. GPP/ER ratios

18 were $>1$ indicating heterotrophic conditions during the study. We found that sites had similar activation energy

19 associated with ER suggesting our work provides a useful reference for estimating temperature corrected

20 metabolic processes for other urban rivers in the region. Structural equation modelling (SEM) revealed that nutrient supply, water temperature and light availability were the main factors driving REM. This research highlights the major environmental factors affecting REM providing needed evidence to inform river restoration and future in-stream management.

Keywords: gross primary production, ecosystem respiration, activation energy, wastewater, River Wandle

Article Highlights

- Sewage effluent resulted in elevated GPP and ER rates.

- Nutrient supply and water temperature jointly promoted GPP and ER rates.

- Inexpensive loggers to estimate river metabolism are needed for river restoration. 
River ecosystem metabolism (REM) is a measure of ecosystem function which integrates gross primary production (GPP) and ecosystem respiration (ER) (Fellows et al. 2006; Rodríguez-Castillo et al. 2019). On a global scale, a major contributor to atmospheric $\mathrm{CO}_{2}$ is from the respiration of riverine organic matter (Beaulieu et al. 2013; Raymond et al. 2013; Jauhiainen et al. 2014), while GPP is important for supporting aquatic biodiversity in river ecosystems (Strayer and Dudgeon, 2010; Ferreira et al. 2020). A wide range of environmental factors affects both GPP and ER (Mulholland et al. 2008; Gernot et al. 2010; Jankowski et al. 2021; Fig. 1a), notably stressors associated with the urban stream syndrome (Meyer et al. 2005; Walsh et al. 2005). For example, increased nutrients from anthropogenic activities, urban impervious surfaces and wastewater treatment plant (WWTP) effluents entering rivers can significantly increase REM in urban rivers by promoting biological activity (Meyer et al. 2005; Dodds 2007; Beaulieu et al. 2013; Fig. 1b). The difference between GPP and ER indicates the carbon budget in the river ecosystem, it is therefore referred to as net ecosystem production (NEP) (Bernhardt et al. 2018). Some studies also use the ratio of GPP to ER to determine whether a river is autotrophic or heterotrophic (Grace and Imberger, 2006; Tank et al. 2010; Escoffier et al. 2018). Considering complex interactions among hydrology, climate, chemistry, and biology, REM has direct implications for water quality and food webs and is an excellent functional indicator of ecological response for environmental change (Tank et al. 2010; RodríguezCastillo et al. 2019; Jankowski et al. 2021) which can be used as a holistic tool for the classification of river ecosystem health (Young et al. 2008, Table 1).

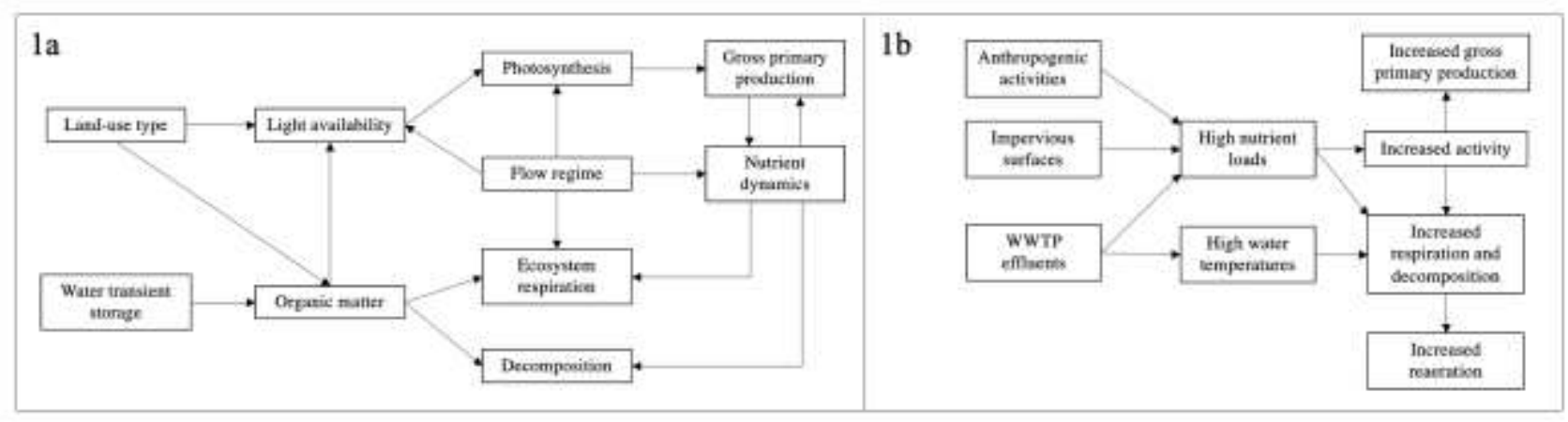

50 Figure 1. River ecosystem metabolism (REM) can be affected by a wider range of factors at multiple scales. a: environmental factors which can influence REM; 1b: examples of factors potentially affecting REM in urban catchments. 
Table 1. Framework for assessing river ecosystem health using metabolism measurements; Impacts refer to the degree of impaired ecosystem functioning (Young et al. 2008). GPP=gross primary production; ER=ecosystem respiration.

\begin{tabular}{ccc}
\hline Assessment parameter & Criterion & Impacts to impaired functioning \\
\hline $\mathrm{GPP}\left(\mathrm{gO}_{2} \cdot \mathrm{m}^{-2} \cdot \mathrm{d}^{-1}\right)$ & $\mathrm{GPP}<3.5$ & Severe effect \\
& $\mathrm{GPP}=3.5-7.0$ & Mild effect \\
& $\mathrm{GPP}>7.0$ & No effect \\
$\mathrm{ER}\left(\mathrm{gO}_{2} \cdot \mathrm{m}^{-2} \cdot \mathrm{d}^{-1}\right)$ & $\mathrm{ER}=1.6-5.8$ & Severe effect \\
& $\mathrm{ER}=0.8-1.6$ or $5.8-9.5$ & Mild effect \\
& $\mathrm{ER}<0.8$ or $>9.5$ & No effect \\
\hline
\end{tabular}

It is widely accepted that polluted rivers with high nutrient and organic matter loads have higher ER which often results in anoxia and hypoxia, a serious water quality problem (Bernhardt et al. 2018). Additionally, WWTP effluents are frequently warmer than ambient stream temperatures which elevate enzymes activity involved in respiration then increase ER rate in urban rivers (Beaulieu et al. 2013; Jauhiainen et al. 2014). For GPP, photosynthesis is strongly influenced by nutrient supply, light availability, and water temperatures (Roberts et al. 2007; Heffernan and Cohen, 2010; Finlay et al. 2011). For example, Bernhardt et al. (2018) noted that GPP often peaks in high nutrient concentrations, warming temperatures and lengthening days.

The respiration process of aquatic organisms is associated with activation energy, which is related to temperature (Yvon-Durocher et al. 2010; Hill et al. 2018). Within a certain temperature range, higher water temperature can promote the activity of enzymes related to respiration, thus improving ER rates and higher activation energy is required, especially for urban rivers receiving WWTP effluents with warmer water temperature (Beaulieu et al. 2013; Jauhiainen et al. 2014). The sensitivity of activation energy to temperature provides a new insight into river water quality management. For example, elevated riverine ER and associated activation energy in summer indicate higher DO consumption, and DO supplementary measures need to be implemented (Perkins et al. 2012).

In this study, we measured REM of the River Wandle, an urban tributary to the River Thames, affected by WWTP effluent. Using the WWTP effluent as a natural experiment, we evaluated how both variations in nutrients and water temperatures affect REM. Additionally, we employed structural equation modelling (SEM), which has been widely used in ecology, to provide regression models to investigate the causality of environmental factors affecting REM (sensu Fan et al. 2016). With this knowledge, we then sought to use our River Wandle case study to inform further river restoration and future in-stream management options.

81 Study sites 

urban coverage of $~ 50 \%$ (Smith and Chadwick, 2014; Lavelle et al. 2019). The river is $14 \mathrm{~km}$ in length with an average discharge of $1.70 \mathrm{~m}^{3} / \mathrm{s}$ (River Wandle Catchment Plan, 2014). Within the catchment, Beddington WWTP serves 360,000 people and discharges into the Wandle (Schnell et al. 2015). The upstream site is located $0.2 \mathrm{~km}$ above WWTP effluent outfall (henceforth U0.2 in the paper); The downstream site located $3 \mathrm{~km}$ below the effluent outfall is referred to as D3.0 (Fig 2). U0.2 has abundant riparian vegetation and submerged macrophytes; D3.0 flows through a residential area.

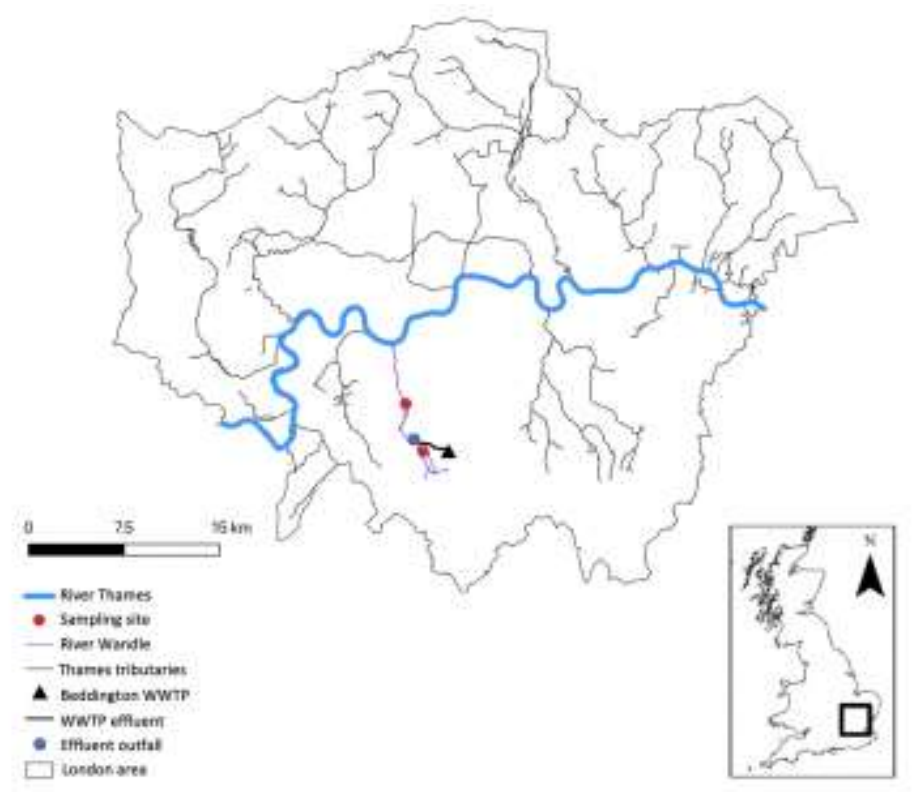

Figure 2. Study sites on the River Wandle, a tributary of the Thames, UK. The blue dot is the outfall location of the WWTP effluent to the river. Red dots are the upstream site (U0.2) and the downstream site (D3.0). The black triangle denotes Beddington WWTP.

93

\section{Water quality and light data}

$50 \mathrm{~mL}$ of water sample was collected and water temperature was measured at each study site (Hanna HI98194 multiparameter meter). Water samples were stored cool separately during transport to the laboratory. In the laboratory, water samples were passed through $0.22 \mu \mathrm{m}$ membrane filters before nutrient measurements. $\mathrm{NO}_{3}{ }^{-}$ and $\mathrm{PO}_{4}{ }^{3-}$ concentrations were measured by ion chromatography (Dionex Aquion). $\mathrm{NH}_{4}{ }^{+}$concentration was measured using Turner Designs AquaFluor handheld fluorometer (Holmes et al. 1999). DOC concentration was measured by total organic carbon (TOC) analyzer (SHIMADZU TOC-L). The website http://environment.data.gov.uk provides data of photosynthetic active radiation (PAR) for the study reaches, which are used as a measure of light availability light availability. 
105 During the study period (19 to 22 September 2019), water levels at U0.2 and D3.0 remained at 0.20-0.25 m, 0.35-

$1060.40 \mathrm{~m}$, respectively (https://flood-warning-information.service.gov.uk). The stable flow conditions were suitable

107 for using the open-water, single station method (Grace and Imberger, 2006; Demars et al. 2015). Specifically, the

108 night-time slope modelling (NSM) was applied for GPP, ER and reaeration estimates in this study (Hill et al.

109 2018), which is based on the principle of no GPP during nighttime to simplify the oxygen mass balance equation

110 (eq. 1, eq. 2) to establish the linear regression between DO change rate and ER. We measured DO and water

111 temperature at both sites simultaneously. Due to the limited number of loggers, these measurements were made

112 using two lab calibrated data loggers (MiniDOT logger and Arduino logger (Chan et al 2020)); collection

113 frequency was once per minute for the MiniDOT logger and 9 times per minute for the Arduino logger.

$$
\frac{\mathrm{dC}_{\mathrm{DO}}}{\mathrm{dt}}=\mathrm{k}\left(\mathrm{C}_{\mathrm{DOs}}-\mathrm{C}_{\mathrm{DO}}\right)+\mathrm{GPP}-\mathrm{ER}
$$

$$
\frac{\mathrm{dC} \text { DO }}{\mathrm{dt}}=\mathrm{k}\left(\mathrm{C}_{\mathrm{DO}}-\mathrm{C}_{\mathrm{DO}}\right)-\mathrm{ER}
$$

116 where $\mathrm{C}_{\mathrm{DO}}$ is DO concentration $(\mathrm{mg} / \mathrm{L}) ; \mathrm{C}_{\mathrm{DOs}}$ is DO saturated concentration $(\mathrm{mg} / \mathrm{L}) ; \mathrm{k}$ is reaeration coefficient $(\mathrm{d}$

$\left.{ }^{1}\right) ; \mathrm{k}\left(\mathrm{C}_{\mathrm{DO}}-\mathrm{C}_{\mathrm{DO}}\right)$ is reaeration rate $(\mathrm{mg} /(\mathrm{Ld}))$.

Oxygen from the atmosphere transported across the air-water interface (reaeration) also causes changes in dissolved oxygen (DO) in rivers (Hill et al. 2018). Reaeration coefficient $k$ measures the speed of the reaeration process (Jin et al. 2012; Omole et al. 2013). Soares et al. (2013) noted that $k$ is proportional to the flow velocity and river channel slope, suggesting that disturbances that speed up water flow can accelerate reaeration (e.g.,

122 flooding) (Raymond et al. 2012). In our study, given the uniform nature of the river channel and river velocities across the study reaches the night-time slope modelling approach was appropriate for estimating $k$ (Grace and Imberger, 2006; Hill et al. 2018).

$$
\mathrm{C}_{\text {DOs }}=1.4276 \exp \left[-173.4292+249.6339\left(\frac{100}{\mathrm{~T}}\right)+143.3483 \ln \left(\frac{\mathrm{T}}{100}\right)-21.8492\left(\frac{\mathrm{T}}{100}\right)\right]
$$
where $\mathrm{T}$ is mean water temperature $(\mathrm{K})$.

The night-time period was selected from the time of sunset to the time when the difference between DO saturation concentration and DO concentration (DO deficit) reached the maximum (Hill et al. 2018). The ER

130 obtained by eq. 2 requires temperature correction, which is related to Arrhenius activation energy $E_{a}$, (i.e., the energy required for respiration of aquatic organisms, Gillooly et al. 2001). Higher $E_{a}$ indicates that ER is more 
133 heterotrophic organisms that do not change significantly on seasonal scales (Perkins et al. 2012; González-Pinzón

134 et al. 2016). Therefore, the calculated ER is used to obtain GPP values in eq. 1 .

$$
\theta_{\mathrm{R}}=\exp \left(\frac{\mathrm{E}_{\mathrm{a}}}{\mathrm{k}_{\mathrm{B}} \mathrm{T}_{0} \mathrm{~T}}\right)
$$

136 where $\mathrm{E}_{\mathrm{a}}$ is Arrhenius activation energy $(\mathrm{eV})$ that was derived from eq. 5:

$$
\ln (E R)=-E_{a}\left(\frac{1}{k_{B} T}-\frac{1}{k_{B} T_{0}}\right)+\ln \left(E R_{0}\right)
$$

138 where $\mathrm{k}_{\mathrm{B}}$ is Boltzmann constant $\left(8.62 \times 10^{-5} \mathrm{eV} / \mathrm{K}\right)$; $\mathrm{T}$ is mean water temperature $(\mathrm{K})$; $\mathrm{T}_{0}$ is reference water temperature $(288.15 \mathrm{~K}) ; \mathrm{ER}_{0}$ is respiration rate at $\mathrm{T}_{0}$.

144 where $\theta_{\mathrm{P}}=1.066$, the correction coefficient.

The temperature-corrected reaeration rate was derived from eq. 8 :

147 where $\theta_{\mathrm{a}}=1.024$, the correction coefficient.

148 GPP, ER and reaeration rate were temperature corrected to obtain the diurnal variation data during the 149 experimental period. Differences in REM between sites were evaluated using Paired T-Tests. Correlations 150 between environmental variables were analyzed using the Pearson correlation coefficients (Table 5a). All data analysis was performed using Excel and SPSS 26.0.

154 By evaluating potential interactions among hydrology, climate, chemistry, and biology (Figs 1a and 1b), we established pathway analysis (Fig. 3) to investigate the influence of the WWTP effluent (i.e., 4 nutrient concentrations in the effluent and elevated water temperatures) on downstream water quality and REM. The arrow points to the affected factor, among them, the nutrient concentrations in the WWTP effluent were derived from

158 Zhang et al. (2021), the PAR data was from http://environment.data.gov.uk, other data, except bioactivity, were derived from our measurements and estimates. Bioactivity (e.g., phytoplankton and aquatic animals) is a variable

160 we did not measure and cannot obtain data directly from literatures or websites (referred to as central latent variable, in the oval) but aquatic organisms are the main body of river metabolic processes. Structural equation 
162 modelling (SEM) allows us to include bioactivity in pathways and estimate its correlations with other measured

163 variables (in the box) (Fan et al. 2016). The SEM was performed in SPSS 21.0 AMOS.

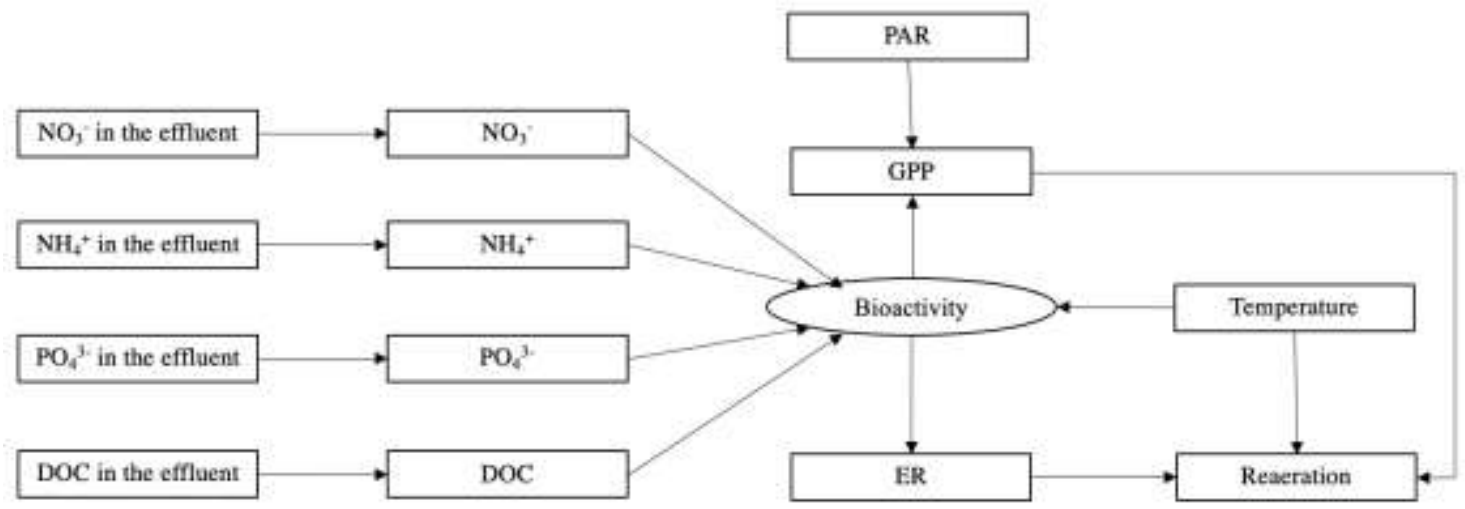

165 Figure 3. Pathway analysis for REM pattern and decomposition process in the reach affected by the WWTP 166 effluent. Variables linked by arrows have causal relationships. The box represents the observed variable; The oval 167 represents the latent variable.

168

169 Results

Light and water flow

171 The data of light availability were measured by PAR for the River Wandle (Table 2a); The water flow data from

172 the South Wimbledon flow monitoring station near to D3.0 (http://nrfa.ceh.ac.uk/data/station/info/39003)

173 provides an opportunity to further study the effect of water flow $Q$ on DO dynamics (e.g., reaeration coefficient

$174 k$, Table 2b).

175 Table 2a. Data of photosynthetic active radiation (PAR) for the River Wandle (http://environment.data.gov.uk).

176 The nighttime PAR (7 pm-5 am) was 0 and was not displayed in the table.

\begin{tabular}{|c|c|c|c|c|c|c|c|c|}
\hline Date & Time & $\begin{array}{c}\text { PAR } \\
\left(\mathrm{KJ} \cdot \mathrm{m}^{-2}\right)\end{array}$ & Time & $\begin{array}{c}\text { PAR } \\
\left(\mathrm{KJ} \cdot \mathrm{m}^{-2}\right)\end{array}$ & Time & $\begin{array}{c}\text { PAR } \\
\left(\mathrm{KJ} \cdot \mathrm{m}^{-2}\right)\end{array}$ & Time & $\begin{array}{c}\text { PAR } \\
\left(\mathrm{KJ} \cdot \mathrm{m}^{-2}\right)\end{array}$ \\
\hline $19 / 09$ & $1-3 \mathrm{pm}$ & 1255.8 & $3-5 \mathrm{pm}$ & 327.6 & $5-7 \mathrm{pm}$ & 112.6 & & \\
\hline $20 / 09$ & $5-7 \mathrm{am}$ & 49.9 & $7-9 \mathrm{am}$ & 691.2 & $9-11 \mathrm{am}$ & 1711.1 & $11-1 \mathrm{pm}$ & 2222.4 \\
\hline & $1-3 \mathrm{pm}$ & 2085.1 & $3-5 \mathrm{pm}$ & 1281.7 & $5-7 \mathrm{pm}$ & 294.4 & & \\
\hline $21 / 09$ & $5-7 \mathrm{am}$ & 47.7 & $7-9 \mathrm{am}$ & 699.2 & $9-11 \mathrm{am}$ & 1705.6 & $11-1 \mathrm{pm}$ & 2205.2 \\
\hline & $1-3 \mathrm{pm}$ & 2030.6 & $3-5 \mathrm{pm}$ & 1213.2 & $5-7 \mathrm{pm}$ & 255.7 & & \\
\hline $22 / 09$ & $5-7 \mathrm{am}$ & 15.0 & $7-9 \mathrm{am}$ & 300.2 & $9-11 \mathrm{am}$ & 924.1 & & \\
\hline
\end{tabular}

178 Table 2b. Data of water flow from the South Wimbledon flow monitoring station near to D3.0 179 (http://nrfa.ceh.ac.uk/data/station/info/39003).

\begin{tabular}{|c|c|c|c|}
\hline Date & Water flow $\left(\mathrm{m}^{3} / \mathrm{s}\right)($ mean $(\min -\mathrm{max}))$ & Date & Water flow $\left(\mathrm{m}^{3} / \mathrm{s}\right)(\mathrm{mean}(\min -\mathrm{max}))$ \\
\hline $19 / 09$ & $1.192(0.637-4.000)$ & $20 / 09$ & $1.161(0.609-5.360)$ \\
\hline $21 / 09$ & $1.224(0.655-4.570)$ & $22 / 09$ & $1.581(0.580-4.170)$ \\
\hline
\end{tabular}

\section{DO profiles}

182 During the experimental period, the sunrise and sunset were around 6:00 am and 6:40pm, respectively. At both 

$\mathrm{mg} / \mathrm{L}$ and $9.50 \pm 0.13 \mathrm{mg} / \mathrm{L}$, respectively.
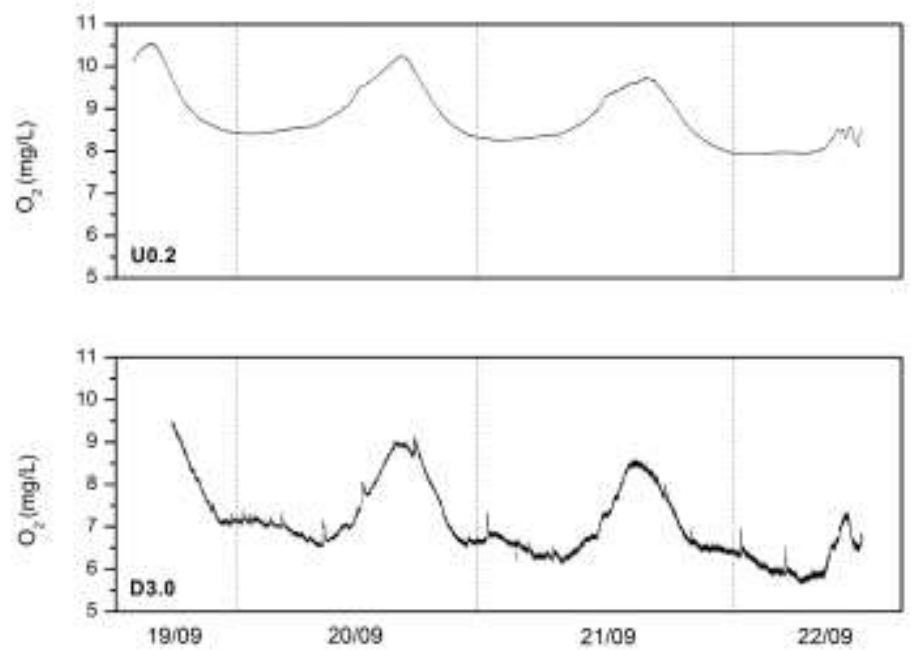

187 Figure 4. Diurnal variation of DO during the study period for the two study sites. U0.2=upstream of WWTP; 188 D3.0=downstream of WWTP.

\section{Reaeration and activation energy estimates}

192 For both sites, the daily temperature-corrected reaeration rate in the nighttime was significantly higher than in the

193 daytime $(p=0.009$, Fig. 5a). The highest reaeration rate was found at D3.0 $(p=0.238)$, where the reaeration coefficient $k$ was significantly lower than at U0.2 ( $p=0.012$, Table 3, Fig. 6) and presented as a function of discharge with a regression coefficient of 0.897 (Fig. 5b). The diurnal reaeration rate was not correlated with ER $\left(r^{2}=0.775\right.$, see below for ER estimates), while the nighttime reaeration rate was positively correlated with ER $\left(r^{2}=0.013\right)$. A similar activation energy required for ER was observed between the two sites (U0.2=0.97 eV, D3.0 $=0.95 \mathrm{eV})$.
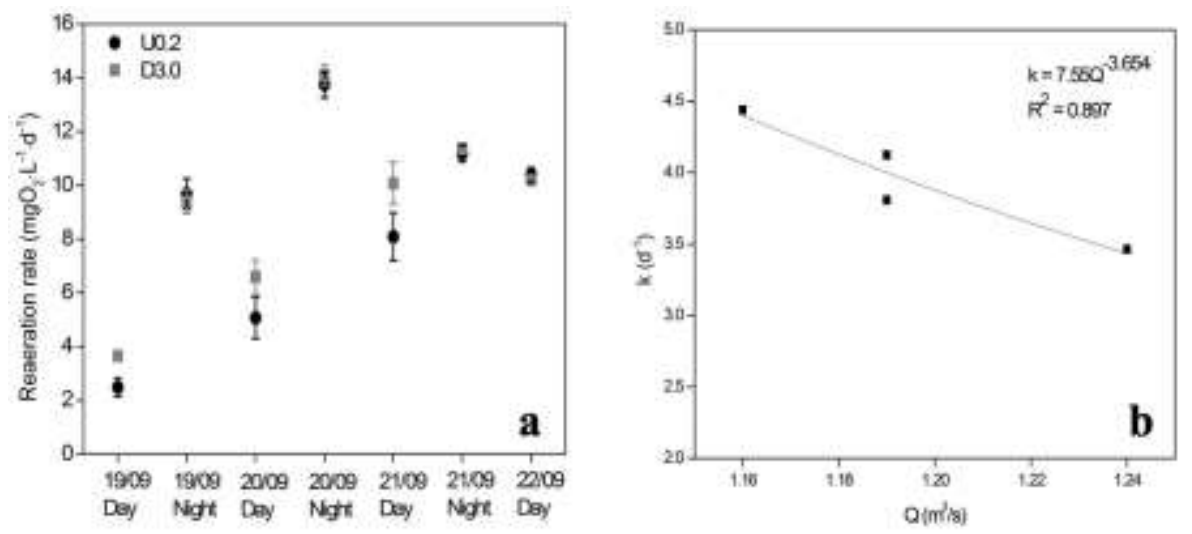

Figure 5. a. Diurnal variation of reaeration rate during the study period for the two study sites. Reaeration was estimated using the night-time slope modelling; b. Reaeration coefficient calculated from the NSM method for D3.0 normalized to $20^{\circ} \mathrm{C}$ with $\theta_{\mathrm{a}}$ during the study period. The flow data was derived from the South Wimbledon flow monitoring station near to D3.0 site (http://nrfa.ceh.ac.uk/data/station/info/39003). 

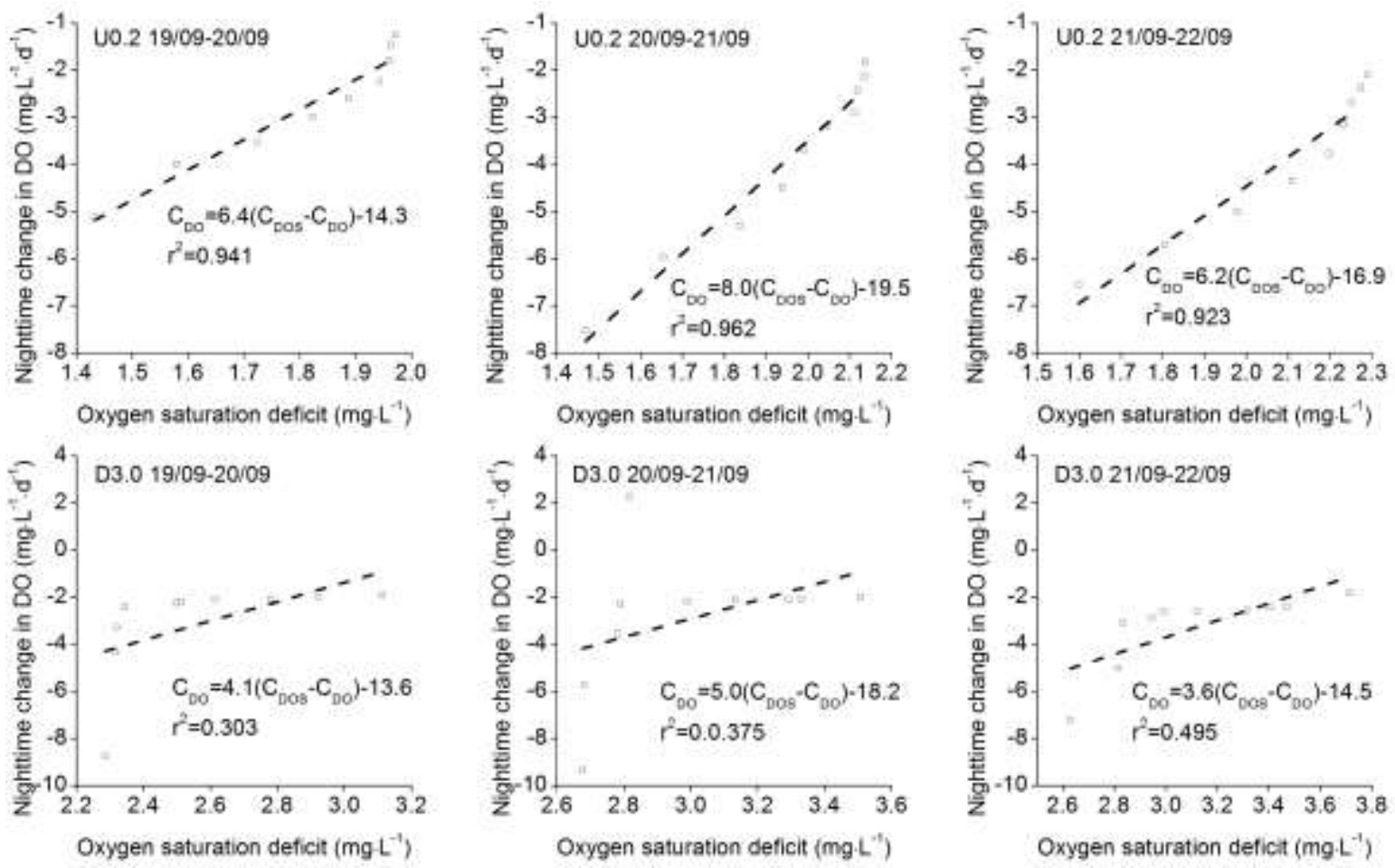

Figure 6. Equations fitted by nighttime slope method (NSM) at two sites during the experimental period.

Table 3. Reaeration coefficient $(k)$ and ecosystem respiration (ER) from eq. 3; Activation energy $\left(E_{a}\right)$ from eq. 5

\begin{tabular}{ccccc}
\hline Site & Night-time & $\boldsymbol{e q . 3}$ & $\boldsymbol{k}\left(\mathbf{d}^{-\mathbf{1}}\right)$ & $\boldsymbol{e q . 5}$ \\
\hline $\mathrm{U} 0.2$ & $19 / 9-20 / 9$ & $\mathrm{y}=6.396 \mathrm{x}-14.347\left(r^{2}=0.941\right)$ & 6.396 & \\
& $20 / 9-21 / 9$ & $\mathrm{y}=8.000 \mathrm{x}-19.493\left(r^{2}=0.962\right)$ & 8.000 & $\mathrm{y}=-0.949 \mathrm{x}+8.539\left(r^{2}=0.985\right)$ \\
& $21 / 9-22 / 9$ & $\mathrm{y}=6.195 \mathrm{x}-16.856\left(r^{2}=0.923\right)$ & 6.195 & \\
\hline $\mathrm{D} 3.0$ & $19 / 9-20 / 9$ & $\mathrm{y}=4.073 \mathrm{x}-13.601\left(r^{2}=0.303\right)$ & 4.073 & \\
& $20 / 9-21 / 9$ & $\mathrm{y}=4.951 \mathrm{x}-18.216\left(r^{2}=0.375\right)$ & 4.951 & $\mathrm{y}=-0.971 \mathrm{x}+2.412\left(r^{2}=0.949\right)$ \\
& $21 / 9-22 / 9$ & $\mathrm{y}=3.595 \mathrm{x}-14.487\left(r^{2}=0.495\right)$ & 3.595 & \\
\hline
\end{tabular}

Note: The intercept of $e q .3$ is ER in $\mathrm{mgO}_{2} \cdot \mathrm{L}^{-1} \cdot \mathrm{d}^{-1}$ and the intercept of $e q .5$ is the logarithm of ER at the reference water temperature $(288.15 \mathrm{~K})$.

\section{GPP, ER and NEP estimates}

214 For both sites, GPP and NEP peaked around 1 3 pm (Fig. 7); GPP ranged from $0 \sim 23.4 \mathrm{mgO}_{2} \cdot \mathrm{L}^{-1} \cdot \mathrm{d}^{-1}$ and NEP

215 ranged from -13.7 13.2 $\mathrm{mgO}_{2} \cdot \mathrm{L}^{-1} \cdot \mathrm{d}^{-1}$ (Table 4). No significant difference in GPP was observed between U0.2 and

216 D3.0 ( $p=0.196)$. GPP was positively correlated with ER, water temperature and regional photosynthetic radiation

217 (Table 5a). ER ranged from $5.4 \sim 16.3 \mathrm{mgO}_{2} \cdot \mathrm{L}^{-1} \cdot \mathrm{d}^{-1}$ (Table 4) and was significantly higher at D3.0 $(11.9 \pm 2.0$

$\left.218 \mathrm{mgO}_{2} \cdot \mathrm{L}^{-1} \cdot \mathrm{d}^{-1}\right)$ compared with $\mathrm{U} 0.2\left(7.1 \pm 1.2 \mathrm{mgO} \cdot \mathrm{L}^{-1} \cdot \mathrm{d}^{-1}, p=0.020\right)$. ER was positively correlated with water

219 temperature $\left(r^{2}=0.889, p<0.001\right)$. At both sites, negative NEP indicated carbon depletion in the river. For D3.0,

220 the higher ER supported a significant higher rate of carbon depletion $(p=0.024)$. Further, ratios of daily GPP to

221 ER were $<1$ (Table 4), indicating that the river was in a heterotrophic state. 

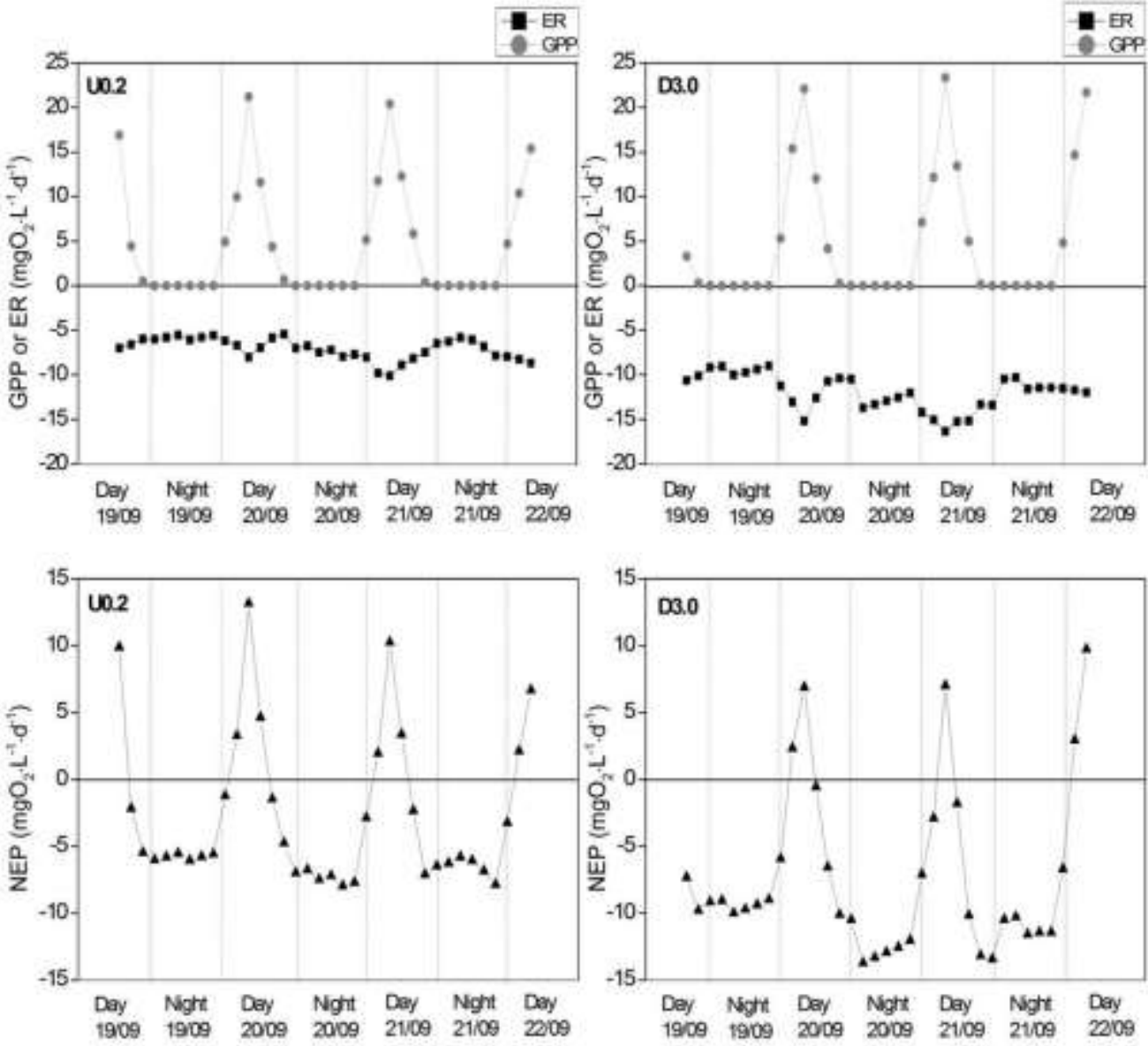

Figure 7. Diurnal variations of GPP, ER and NEP during the study period. Daytime hours were 7:00 am - 6:40 pm, nighttime hours were 6:40 pm - 7:00 am. Data measurement for U0.2 and D3.0 started at 1:00 pm and 3:00 pm on September 19 and ended at 12:00 pm and 1:00 pm on September 22, respectively. GPP=gross primary production; $\mathrm{ER}=$ ecosystem respiration; $\mathrm{NEP}=$ net ecosystem production; U0.2=upstream of WWTP; D3.0= downstream of WWTP.

Table 4. Site-specific river ecosystem metabolism (GPP \& ER) and associated energy input and output of the River Wandle. $\mathrm{GPP}=$ gross primary production; $\mathrm{ER}=$ ecosystem respiration.

\begin{tabular}{cllll}
\hline Site & $\begin{array}{l}\mathbf{G P P} \\
\left(\mathbf{m g O}_{\mathbf{2}} \cdot \mathbf{L}^{-\mathbf{1}} \cdot \mathbf{d}^{\mathbf{- 1}}\right)\end{array}$ & $\begin{array}{l}\mathbf{E R} \\
\left(\mathbf{m g O}_{2} \cdot \mathbf{L}^{-\mathbf{1}} \cdot \mathbf{d}^{-\mathbf{1}}\right)\end{array}$ & $\mathbf{G P P / E R}$ & $\begin{array}{l}\mathbf{N E P} \\
\left(\mathbf{m g O}_{2} \cdot \mathbf{L}^{-\mathbf{1}} \cdot \mathbf{d}^{-\mathbf{1}}\right)\end{array}$ \\
\hline $\mathrm{U} 0.2$ & $4.471(0 \sim 21.20)$ & $7.055(5.45 \sim 10.11)$ & $0.634(0 \sim 2.64)$ & $-2.584(-7.95 \sim 13.18)$ \\
$\mathrm{D} 3.0$ & $4.722(0 \sim 23.36)$ & $11.942(8.98 \sim 16.34)$ & $0.395(0 \sim 1.82)$ & $-7.220(-13.70 \sim 9.75)$ \\
\hline
\end{tabular}

Note: GPP and ER are averages followed by $(\min \sim \max )$ values for the study period.

Table 5a. Correlation matrix among metabolism and nutrients and environmental factors of the River Wandle.

\begin{tabular}{|c|c|c|c|c|c|}
\hline & GPP & ER & Temp & Light & Nitrate \\
\hline GPP & & & & & \\
\hline ER & $r^{2}=0.900 * * *$ & & & & \\
\hline Temp & $r^{2}=0.858 * * *$ & $r^{2}=0.889 * * *$ & & & \\
\hline Light & $r^{2}=0.907 * * *$ & $r^{2}=0.570 * *$ & $r^{2}=0.682 * * *$ & & \\
\hline Nitrate & $r^{2}=0.403 *$ & $r^{2}=0.901 * * *$ & $r^{2}=-0.788 * * *$ & $r^{2}=0.383$ N/A & \\
\hline Phosphate & $r^{2}=-0.806 * * *$ & $r^{2}=0.546 * *$ & $r^{2}=0.874 * * *$ & $r^{2}=0.725 * * *$ & $r^{2}=0.381$ N/A \\
\hline
\end{tabular}

Note: “*” indicates a significant difference of $p<0.05$; “**” indicates a significant difference of $p<0.01$; “****” indicates a significant difference of $p<0.001$; "N/A" indicates no significant difference.

Table 5b. A summary of nutrient concentrations $(\mathrm{mg} / \mathrm{L})$ and water temperatures $\left({ }^{\circ} \mathrm{C}\right)$

\begin{tabular}{llllll}
\hline Site & $\mathbf{N O}_{3}{ }^{-}$ & $\mathbf{N H}_{4}{ }^{+}$ & $\mathbf{P O}_{4}{ }^{3-}$ & DOC & Temp \\
\hline U0.2 & 6.09 & 0.09 & 0.08 & 2.00 & 14.80
\end{tabular}




\begin{tabular}{llllll}
\hline & $(1.11)$ & $(0.02)$ & $(0.05)$ & $(0.56)$ & $(1.33)$ \\
D3.0 & 10.65 & 0.32 & 0.66 & 4.72 & 17.67 \\
& $(1.23)$ & $(0.14)$ & $(0.25)$ & $(0.26)$ & $(1.13)$ \\
\hline
\end{tabular}

Note: Values in parathesis denote one standard error.

241 correlation between phosphate and GPP was observed (Table 5a), suggesting significant impacts of nutrient

242 supply on aquatic biological activities involved in river metabolism. Further, significant positive correlations 243 between GPP and PAR were recorded at both sites $\left(r^{2}=0.921, p<0.001\right.$ for U0.2; $r^{2}=0.829, p<0.001$ for D3.0, Fig.

244 8), suggesting that the GPP determined by the NSM method was reasonable.
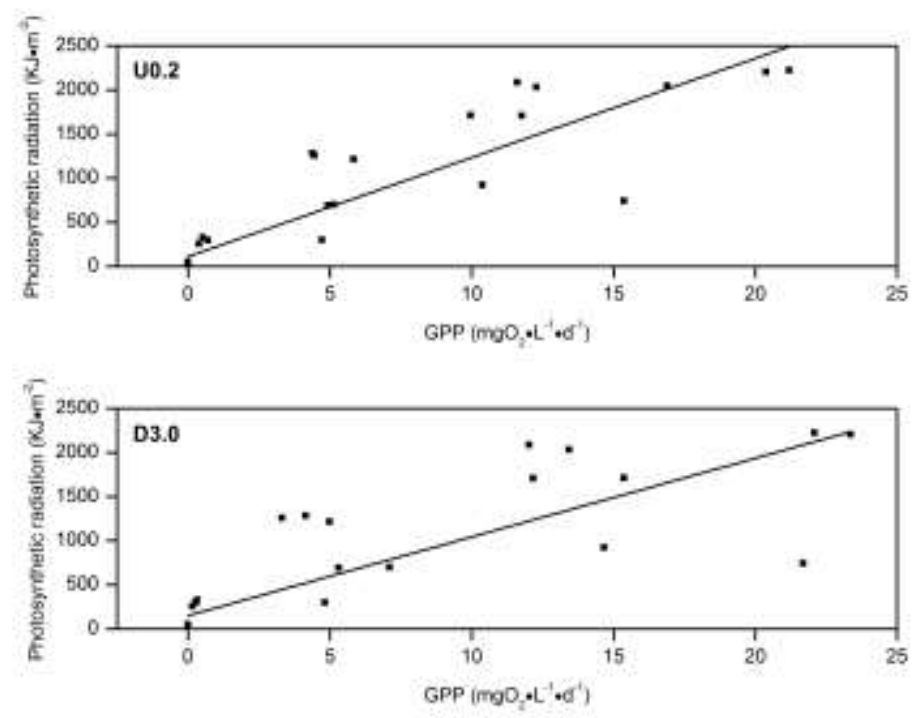

246 Figure 8. Correlation between GPP and PAR during the study period at two study sites.

\section{SEM regression analysis}

249 To investigate the effects of downstream nutrients (at site D3.0) affected by the WWTP effluent and light 250 availability and water temperature on river metabolism, we obtained correlation coefficients from running SEM

251 (Fig. 9; Table A1). The SEM allows to include bioactivity without data into the pathways and estimate the 252 correlations between bioactivity and metabolic processes (i.e., GPP and ER), water quality (i.e., nutrients and water temperature) and light availability through regression calculations. 


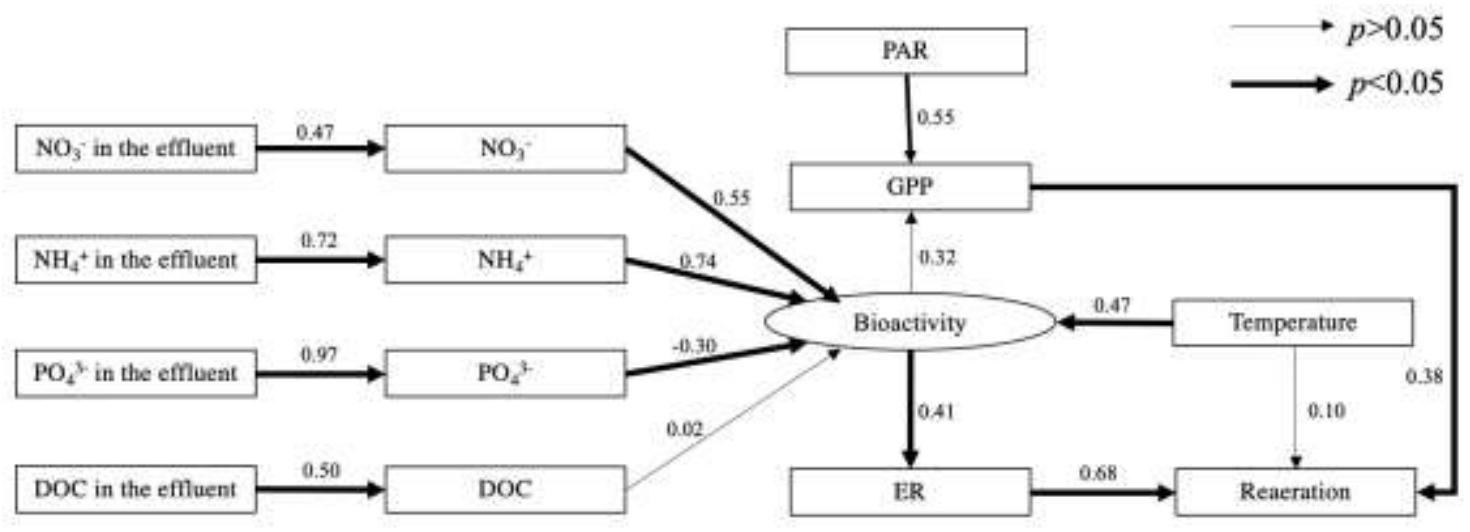

255 Figure 9. Standardized SEM results. The numbers on the arrows represent the correlation coefficient; thicker arrows indicate significant correlations.

The four nutrients in the WWTP effluent all contributed significantly to the elevated nutrient concentrations in the WWTP-affected reach (Fig. 8), resulting in differences in the rates of REM-related processes (Table 4). Although no significant effect of DOC on bioactivity was observed, we still noted that other nutrients and water temperature contributed significantly to bioactivity, thus affecting ER, which played a decisive role in reaeration rates, suggesting that the DO consumed by ER will be significantly supplemented by reaeration. For GPP, it was directly controlled by light availability (PAR).

\section{Discussion}

\section{Comparison with other studies}

We compared our results with other rivers also receiving WWTP effluents or in similar conditions (e.g., elevated temperature and nutrients) in different regions. Overall, reported GPP and ER values for these studies were within the range of our results (our results were multiplied by the water depth to make the units consistent, U0.2 $=0.25$ $\mathrm{m}, \mathrm{D} 3.0=0.40 \mathrm{~m}$, Table 6 ), supporting the role of WWTP effluents and associated conditions in regulating REM, despite different channel characteristics, nutrient loads, aquatic organism composition, and local climate might contribute to the differences in these results.

274 than in the reference reaches in six urban rivers in Wisconsin, USA, which was consistent with the significantly elevated ER we observed at D3.0. Fuß et al. (2017) reported that the ranges of GPP and ER in agricultural rivers with highly loaded DOM and nitrates (i.e., like the WWTP effluent) were higher than in the forest rivers and covered the range at D3.0 in our study. Similarly, Rodríguez-Castillo et al. (2019) reported that the GPP and ER thresholds in the effluent-impacted reach of the River Cares, Spain, were within the range at D3.0. Arroita et al. 
280 River Oria, Spain. However, in many studies on river metabolism, including our study, GPP and ER estimates

281 were based on river reaches and did not indicate which part of the river they came from (e.g., algae, aquatic 282 macrophytes), which requires further research. 
283 Table 6. Comparison between river ecosystem metabolism (REM) for this study and other similar published studies. Reported GPP and ER ranges or mean 284 values for these studies were within the range of our results. This finding supports the role of WWTP effluents and associated conditions in regulating REM.

\begin{tabular}{|c|c|c|c|c|c|c|}
\hline Authors & River location & $\begin{array}{l}\text { River size } \\
\left(\mathbf{k m}^{2}\right)\end{array}$ & $\begin{array}{l}\text { River } \\
\text { characteristics }\end{array}$ & Methods & $\begin{array}{l}\text { GPP } \\
\left(\mathrm{gO}_{2} /\left(\mathbf{m}^{2} \bullet \mathbf{d}\right)\right)\end{array}$ & $\begin{array}{l}\text { ER } \\
\left(\mathbf{g O}_{2} /\left(\mathbf{m}^{2} \bullet \mathbf{d}\right)\right)\end{array}$ \\
\hline This study & $\begin{array}{l}\text { River Wandle, } \\
\text { London, UK }\end{array}$ & 11 & $\begin{array}{l}\text { Reference \& } \\
\text { effluent }\end{array}$ & Single-station & $\begin{array}{l}1.1(0-5.3) \text { (ref) } \\
2.1(0-10.5) \text { (effluent) }\end{array}$ & $\begin{array}{l}1.8 \text { (1.4 - 2.5) (ref) } \\
5.4 \text { (4.0 - 7.4) (effluent) }\end{array}$ \\
\hline $\begin{array}{l}\text { Levi and McIntyre } \\
\text { (2020) }\end{array}$ & $\begin{array}{l}\text { Urban rivers, } \\
\text { Wisconsin, USA }\end{array}$ & $3.0-55.4$ & $\begin{array}{l}\text { Reference \& } \\
\text { effluent }\end{array}$ & Modelling & $\begin{array}{l}1.4 \text { (ref) } \\
17.4 \text { (effluent) }\end{array}$ & $\begin{array}{l}1.6 \text { (ref) } \\
11.0 \text { (effluent) }\end{array}$ \\
\hline Fuß et al. (2017) & $\begin{array}{l}\text { Rivers in central } \\
\text { Europe }\end{array}$ & $15.8-316.4$ & $\begin{array}{l}\text { Agricultural \& } \\
\text { forest }\end{array}$ & Single-station & $\begin{array}{l}0.01-0.9 \text { (forest) } \\
1.0-3.3 \text { (agriculture) }\end{array}$ & $\begin{array}{l}1.9-6.0 \text { (forest) } \\
6.2-11.7 \text { (agriculture) }\end{array}$ \\
\hline $\begin{array}{l}\text { Rodríguez-Castillo } \\
\text { et al. (2019) }\end{array}$ & $\begin{array}{l}\text { Deva-Cares } \\
\text { catchment, Spain }\end{array}$ & 495 & $\begin{array}{l}\text { Reference \& } \\
\text { effluent }\end{array}$ & $\begin{array}{l}\text { DO record \& } \\
\text { modelling }\end{array}$ & $\begin{array}{l}<2.5 \text { (ref) } \\
>2.5 \text { (effluent) }\end{array}$ & $\begin{array}{l}<2.5 \text { (ref) } \\
2.5-3.5 \text { (effluent) }\end{array}$ \\
\hline Aristi et al. (2015) & $\begin{array}{l}\text { Segre River, } \\
\text { Iberian Peninsula }\end{array}$ & 287 & $\begin{array}{l}\text { Reference \& } \\
\text { effluent }\end{array}$ & $\begin{array}{l}\text { Single-station } \\
\& \text { two-station }\end{array}$ & $\begin{array}{l}0.54 \text { (ref) } \\
0.7-2.3 \text { (effluent) }\end{array}$ & $\begin{array}{l}3.1 \text { (ref) } \\
6.6-8.8 \text { (effluent) }\end{array}$ \\
\hline $\begin{array}{l}\text { Escoffier et al. } \\
\text { (2018) }\end{array}$ & $\begin{array}{l}\text { Urban part of the } \\
\text { Seine River, } \\
\text { France }\end{array}$ & 18,748 & Effluent & Single-station & $0.04-15.7$ (effluent) & $0.03-17.6$ (effluent) \\
\hline Arroita et al. (2018) & $\begin{array}{l}\text { River Oria, } \\
\text { Alegia, Spain }\end{array}$ & 333 & $\begin{array}{l}\text { Before and after a } \\
\text { WWTP installation }\end{array}$ & Single-station & $\begin{array}{l}6.8 \text { (before) } \\
3.8 \text { (after) }\end{array}$ & $\begin{array}{l}12.4 \text { (before) } \\
4.22 \text { (after) }\end{array}$ \\
\hline
\end{tabular}


287 The continuous monitoring of DO concentrations provides information about anoxia and hypoxia, which are vital 288 for evaluating habitat suitability for aquatic organisms (Pollock et al. 2007; Rode et al. 2016; Elosegi et al. 2017).

289 The magnitude of diurnal DO swings at D3.0 was higher than at U0.2 resulting from high rates of photosynthesis

290 and organic matter respiration (Fig. 5), which can cause physiological stress in aquatic organisms (Pollock et al.

291 2007). Regarding spatial distributions of DO, affected by the WWTP effluent, the mean DO concentration at D3.0

292 was lower, but the DOC concentration was higher (Table 5b), indicating that respiration supported by DOC 293 contributed to DO consumption (Fig. 9). Additionally, high concentrations of DOC were partly attributed to the 294 decomposition of organic matter, which also consumed DO and needs further investigation in these reaches (Ferreira et al. 2020). around 6:30 am at D3.0. On the one hand, the lower nighttime water temperature resulted in high concentrations of saturated DO; On the other hand, the DO concentration was lower in the nighttime, leading to the maximum DO deficit at night (Hill et al. 2018). The SEM model revealed that the higher water temperature and nutrient supply of the WWTP effluent at D3.0 promoted the consumption of DO by ER (Fig. 9), which significantly increased the reaeration rate to supplement DO (Fig. 5a), resulting in the maximum DO deficit at D3.0 occurring later than at U0.2.

303

\section{Factors driving GPP and ER}

WWTP effluent in this study was used as a natural experiment to investigate the effects of nutrient loads and elevated water temperatures on urban river ecosystem metabolism. We found that the WWTP effluent resulted in similar GPP ( $p=0.196)$, but higher ER ( $p=0.020)$ in the WWTP-affected reach (Fig. 7). These results are like other research which have evaluated REM in streams affected by similar stressors to our study (e.g., elevated temperatures and nutrients, Table 6). Further, based on the criteria reported in Table 1, our study sites would be

310 classified as severely to mildly impaired. Although GPP and ER were measured at specific locations, they can

311 represent the metabolic patterns of the studied reaches and be used to assess ecological functions, because of the

312 natural movement and mixing of water in a river (Young et al. 2008). Overall, this suggests that both the WWTP 313 effluent and the urbanized catchment have negative impacts on river ecological function and health.

314 The Beddington WWTP effluents had elevated nutrients, such as nitrates and phosphates, relative to the 315 ambient River Wandle water quality during our study and this has been reported previously (Millier et al. 2010; 
316 South East Rivers Trust, 2010). Available nitrogen and phosphorus often act as limiting nutrients for aquatic

317 vegetation (Woodward et al. 2012; Bristow et al. 2017). The SEM model revealed that $\mathrm{NO}_{3}{ }^{-}, \mathrm{NH}_{4}{ }^{+}$and $\mathrm{PO}_{4}{ }^{3-}$ were

318 key nutrients affecting aquatic biological activity, and these increases can promote the growth and reproduction

319 of aquatic organisms (e.g., phytoplankton), thus accelerating GPP and ER (Tank and Dodds, 2003; Noormets,

320 2009). Aristi et al. (2015) referred to the increase in GPP and ER in heterotrophic rivers as the "subsidy" effect of

321 WWTP effluents. As a result of this, a positive correlation between GPP and ER was found $\left(r^{2}=0.900, p<0.001\right)$,

322 which has also been widely reported by many studies (e.g., Chen et al. 2009; Hall and Beaulieu, 2013 ; Yan et al.

323 2018; Hung et al. 2020). However, organic matter associated with WWTP effluents (e.g., higher DOC

324 concentrations at D3.0) can be an important energy input exceeding in-situ GPP (Gücker et al. 2006; Aristi et al.

325 2015); Additionally, GPP is directly controlled by light availability (Griffiths et al. 2013; Ferreira et al. 2020).

326 Therefore, the increase for ER and GPP in reaches with elevated nutrients are not always consistent (Bernhardt et

327 al. 2018), which explains the inconsistency between the increased significance of GPP and ER at D3.0 in our

328 study. Furthermore, changes of light availability led to the diurnal variation of GPP as we observed that the GPP

329 was the highest between 11 am and $1 \mathrm{pm}$ then decreased to 0 in the nighttime (Fig. 7). Reach-scale riparian

330 vegetation is also a key factor affecting GPP because abundant riparian vegetation blocks the light transmission

331 into the river, as the case at U0.2, resulting in lower GPP values at U0.2 in our study (Wondzell et al. 2019; Tan

332 et al. 2021, Table 4).

333 ER was positively correlated with water temperatures $\left(r^{2}=0.889, p<0.001\right)$ due to temperature-related

334 enzymes activity involved in respiration (Beaulieu et al. 2013; Jauhiainen et al. 2014). The SEM model also

335 showed that biological activity was significantly affected by water temperature, which in turn affected ER. As a

336 result, due to the warm WWTP effluent (Table 5b), ER at D3.0 was significantly higher than at U0.2 ( $p=0.020)$.

337 However, ER will not increase indefinitely with increasing temperature due to factors like substrate limitation

338 and/or protein degradation (Demars et al. 2011; Manning et al. 2018). As a result, with the continuous DO

339 consumption by ER and decomposition and the potentially limited carbon supply due to the metabolism of carbon

340 compounds, the maximum DO deficit was reached before sunrise and the initiation of photosynthesis (Hill et al.

341 2018). In some systems, this can produce anoxic or hypoxic periods (Reid et al. 2019), but this was not the case

342 during our study. By studying the decomposition of organic matter in the five tributaries of the Thames River in

343 London, Lavelle (2018) proposed that water temperature can also promote the decomposition process thus

344 accelerating the DO consumption, which likely caused biological activity (e.g., invertebrates and microbes) at 
345 D3.0 with elevated water temperature and nutrients to be stimulated (Woodward et al. 2012), resulting in higher

346 DO consumption, which needs to be further explored in our study river.

347 River respiration is more sensitive to temperatures and more vulnerable to climate change when higher 348 activation energy $\left(E_{a}\right)$ is required (Perkins et al. 2012), however, similar $E_{a}$ was observed between both sites 349 (U0.2=0.97 eV, D3.0=0.95 eV) in our study, which could be applied to other rivers in the region for making temperature corrections to metabolic processes (Hill et al. 2018). However, these two results are higher than the average activation energy $(0.65 \mathrm{eV})$ of river respiration proposed by Yvon-Durocher et al. (2010), which is likely due to the narrow reaches and dense distribution of aquatic vegetation (e.g., phytoplankton) in our study compared with most rivers, resulting in higher ER and required activation energy (Gillooly et al. 2001; Hill et al. 2018).

The balance of GPP and ER plays an important role in the carbon cycle which are affected by anthropogenic factors, such as WWTP effluents and DOM inputs (Kaushal et al. 2014). As we found, WWTP effluent significantly increased ER which has implications for $\mathrm{CO}_{2}$ emissions. According to the respiratory quotient of 0.85 (Grace and Imberger, 2006), U0.2 and D3.0 released $8.228 \mathrm{~g} / \mathrm{m}^{3}$ and $13.948 \mathrm{~g} / \mathrm{m}^{3}$ of $\mathrm{CO}_{2}$ respectively on average during the study period. Strategies to reduce nutrient loads in WWTP effluents via improved WWTP operations are paramount to reducing overall ER in affected systems, thereby lowering the associated $\mathrm{CO}_{2}$ emissions (de la Barrera and Hooda, 2016).

\section{Factors driving reaeration}

363 Significantly increased nighttime reaeration was mainly due to the lack of oxygen supply from photosynthesis;

364 Also, the lower water temperature at night promoted oxygen solubility (Roberts et al. 2007). There was no correlation between diurnal reaeration rates and ER, but a positive correlation was found between nighttime reaeration rates and ER $\left(r^{2}=0.013\right)$, indicating that the nighttime reaeration replenished the DO consumed by ER, and GPP contributed to daytime DO replenishment in addition to reaeration. The higher reaeration rate at D3.0 was closely linked to higher ER caused by the effluent (Fig. 9). As a result, positive values of reaeration rate were observed at night, representing the oxygen entering the river from the atmosphere; In the daytime, the reaeration rate was sometimes negative, representing the saturated DO escaped from the river to the atmosphere (see supplementary materials). Conversely, U0.2 was estimated by a significantly increased reaeration coefficient $k$, which we relate mainly to river features and substrate. The U0.2 reach is wide and shallow with natural substrates

373 (e.g., cobbles) when compared to D3.0. These features provide a large frictional contact area for oxygen disturbance to water flow and oxygen-water mixing even under baseflow conditions (Zappa et al. 2007; Alin et 

scale turbulence leading to increased reaeration coefficients (Nifong, et al. 2020). As $k$ is primarily physically driven, in our study, $k$ is a power function of discharge $Q$ (Fig. 5b), which is consistent with the results of Hill et al. (2018).

Both GPP and reaeration play a key role in increasing DO content, and many riverine ecological restoration practices are based on increasing GPP or reaeration to avoid anoxia (Levi and McIntyre, 2020). With the River Wandle, the river was re-meandered by constructing berms, riffles and marginal wetlands to encourage aquatic vegetation habitats and enhance GPP (Pretty et al. 2003; Bukaveckas, 2007; Lorenz et al. 2013). For other urban rivers, increasing biotic habitat through natural channel design (Reisinger et al. 2019) or providing benthic habitat through rock deployment in the channel (Levi and McIntyre, 2020) are also ways to enhance GPP. Regarding the improvement of reaeration, enhanced oxygen exchange by flow sinuosity can be achieved by deploying wood, spoil or stones in the channel, such as the Pool River (River Restoration Centre, 2012) and the Hogsmill River (South East Rivers Trust, 2013) in London, UK. Improving GPP and reaeration should therefore be goals of further river restoration practice. However, elevated ER can result in a reduced NEP as in the case of D3.0 in our study, indicating a net loss of energy and an increased risk of anoxia. We suggest that REM estimates could therefore be used as benchmarks for both river restoration success and overall river health.

\section{Conclusions}

392 Our results showed that significant increased ER downstream of the WWTP effluent was associated with both 393 elevated water temperatures and nutrients. Increased ER resulted in elevated oxygen deficit and associated reaeration rate elucidated by our structural equation modelling exercise. During stable river discharge, we found that both sites were heterotrophic and no significant difference in GPP was observed. When compared to other studies, our results support the finding that urban rivers affected by WWTP effluents (or with elevated nutrient loads) have comparable levels of river ecosystem metabolism (REM) with similar ranges of GPP and ER. Future work should focus on evaluating the roles of storm flows and seasonal climate environments in affecting GPP, ER and NEP in urban rivers and to what extend restoration effort can be used to modify REM. For example, improving instream conditions by promoting reaeration and aquatic primary production should be considered and REM measurements could become robust benchmarks for evaluating restoration success and overall river ecosystem health. Finally, we suggest that utilizing WWTP effluents across a wide range of rivers as a natural experiment is a powerful approach for understanding how river ecosystems will be affected by future climate change and eutrophication scenarios. 


\section{Acknowledgement}

406 The authors thank Dr. Francis O’Shea, Dr. Kate Olde and Dr. Bruce Main for providing the laboratory and

407 assisting in the use of experimental equipment. This research was partly funded by the Department of Geography,

408 King's College London.

409 Declarations

410 Funding: This research was supported in part by the Department of Geography, King's College London.

411 Conflicts of interest/Competing interests: N/A

412 Availability of data and material: All data are provided within the paper and supplementary spreadsheet.

413 Authors' contributions: M Zhang and M Chadwick designed the research. M Zhang led the field and lab work and

414 wrote the first draft of the manuscript. All authors contributed editing and completion to the final draft. 
Alin, S., Fátima, F., Rasera, M., Salimon, C., Richey, J., Holtgrieve, G., Krusche, A., \& Snidvongs, A. (2011). Physical controls on carbon dioxide transfer velocity and flux in low-gradient river systems and implications for regional carbon budgets. Journal of Geophysical Research Biogeosciences, 116(G1). https://doiorg/101029/2010JG001398

Arroita, M., Elosegi, A., \& Hall, R. (2018). Twenty years of daily metabolism show riverine recovery following sewage abatement. Limnology and Oceanography, 64, 77-92. https://doiorg/101002/Ino11053

Beaulieu, J., Arango, C., Balz, D., \& Shuster, W. (2013). Continuous monitoring reveals multiple controls on ecosystem metabolism in a suburban stream. Freshwater Biology, 58(5), 918-937. https://doiorg/101111/fwb12097

Bernhardt, E, S., Heffernan, J, B., Grimm, N, B., Stanley, E, H., Harvey, J, W., Arroita, M., Appling, A, P., Cohen, M, J., McDowell, W, H., Hall, R, O., Read, J, S., Roberts, B, J., Stets, E, G., \& Yackulic, C, B. (2018). The metabolic regimes of flowing waters. Limnology and Oceanography, 63(S1), S99-S118. https://doi.org/10.1002/lno.10726

Bernot, M, J., Sobota, D, J., Hall, R, O., Mulholland, P, J., Ddodds, W, K., Webster, J, R., Tank, J, L.,

Bristow, L, A., Mohr, W., Ahmerkamp, S., \& Kuypers, M, M. (2017). Nutrients that limit growth in the ocean. Current Biology, 27(11), 474-478. https://doi.org/10.1016/j.cub.2017.03.030

Bukaveckas, P, A. (2007). Effects of channel restoration on water velocity, transient storage, and nutrient uptake in a channelized stream. Environmental Science \& Technology, 41(5), 1570-1576.

443 Chan, K., Schillereff, D., Baas, A., Chadwick, M., Main, B., Mulligan, M., O’Shea, F., Pearce, R., Smith, T., Soesbergen, A., Tebbs, E., \& Thompson, J. (2020). Low-cost electronic sensors for environmental 

https://doi.org/10.1177/0309133320956567

447 Chen, C, C., Shiah, F, K., Chiang, K, P., Gong, G, C., \& Kemp, W, M. (2009). Effects of the Changjiang (Yangtze) River discharge on planktonic community respiration in the East China Sea. Journal of Geophysical Research: Oceans, 114, 1-15. https://doi.org/10.1029/2008JC004891

de la Barrera, B., \& Hooda, P, S. (2016). Greenhouse gas emissions of waste management processes and options: a case study. Waste Management \& Research, 34(7), 658-665. https://doi.org/10.1177/0734242X16649680

Demars, B, L., Thompson, J., \& Manson, J, R. (2015). Stream metabolism and the open diel oxygen method: Principles, practice, and perspectives. Limnology and Oceanography, Methods, 13(7), 356-374. https://doi.org/10.1002/lom3.10030

Demars, B. O., Manson, J. R., Ólafsson, J. S., Gíslason, G. M., \& Friberg, N. (2011). Stream hydraulics and

Dodds, W, K. (2007). Trophic state, eutrophication and nutrient criteria in streams. Trends in Ecology \& Evolution, 22(12), 669-676. https://doi.org/10.1016/j.tree.2007.07.010

Elosegi, A., Gessner, M, O., \& Young, R, G. (2017). River doctors: Learning from medicine to improve ecosystem management. The Science of the Total Environment, 595, 294-302. https://doi.org/10.1016/j.scitotenv.2017.03.188

Escoffier, N., Bensoussan, N., Vilmin, L., Flipo, N., Rocher, V., David, A., Métivier, F., \& Groleau, A. (2018). Estimating ecosystem metabolism from continuous multi-sensor measurements in the Seine River. Environmental Science and Pollution Research International, 25(24), 23451-23467. https://doi.org/10.1007/s11356-016-7096-0 https://doi.org/10.1007/s10750-005-9001-6 
Ferreira, V., Elosegi, A., Tiegs, S, D., Schiller, D, V., \& Young, R. (2020). Organic matter decomposition and ecosystem metabolism as tools to assess the functional integrity of streams and rivers-A systematic review. Water (Basel), 12(3523), 3523-. https://doi.org/10.3390/w12123523

Finlay, J, C. (2011). Stream size and human influences on ecosystem production in river networks. Ecosphere, 2(8), 1-21. https://doi.org/10.1890/ES11-00071.1

Fuß, T., Behounek, B., Ulseth, A, J., \& Singer, G, A. (2017). Land use controls stream ecosystem metabolism by shifting dissolved organic matter and nutrient regimes. Freshwater Biology, 62(3), 582-599. https://doi.org/10.1111/fwb.12887

Gillooly, J, F., Brown, J, H., West, G, B., Savage, V, M., \& Charnov, E, L. (2001). Effects of size and temperature on metabolic rate. Science, 293(5538), 2248-2251. https://doi.org/10.1126/science.1061967

González-Pinzón, R., Peipoch, M., Haggerty, R., E Martí, \& Fleckenstein, J, H. (2016). Nighttime and daytime respiration in a headwater stream. Ecohydrology, 1, 93-100. https://doi.org/10.1002/eco.1615

Grace, M. \& Imberger, S. (2006). Stream metabolism: performing \& interpreting measurements. Water Studies

Griffiths, N, A., Tank, J, L., Royer, T, V., Roley, S, S., Rosi-Marshall, E, J., Whiles, M, R., Beaulieu, J, J., \& Centre Monash University, Murray Darling Basin Commission and New South Wales Department of

Hall, R, O., \& Beaulieu, J, J. (2013). Estimating autotrophic respiration in streams using daily metabolism data. Johnson, L, T. (2013). Agricultural land use alters the seasonality and magnitude of stream Freshwater Science, 32(2), 507-516. https://doi.org/10.1899/12-147.1

Heffernan, J, B., \& Cohen, M, J. (2010). Direct and indirect coupling of primary production and diel nitrate dynamics in a subtropical spring-fed river. Limnology and Oceanography, 55(2), 677-688. https://doi.org/10.4319/lo.2010.55.2.0677 
Hill, N, B., Riha, S, J., \& Walter, M, T. (2018). Temperature dependence of daily respiration and reaeration rates during baseflow conditions in a northeastern U.S. stream. Journal of Hydrology. Regional Studies, 19, 250-264. https://doi.org/10.1016/j.ejrh.2018.09.006

Holmes, R, M., Aminot, A., Kerouel, R., Hooker, B, A., \& Peterson, B, J. (1999). A simple and precise method for measuring ammonium in marine and freshwater ecosystems. Canadian Journal of Fisheries and Aquatic Sciences, 56(10), 1801-1808. https://doi.org/10.1139/cjfas-56-10-1801

Hornberger, M. \& Kelly, G. (1975). Atmospheric reaeration in a river using productivity analysis. Journal of the Environmental Engineering Division, 101(5), 729-739.

Hung, J, J., Wang, Y, J., Tseng, C, M., \& Lee Chen, Y, L. (2020). Controlling mechanisms and cross linkages of ecosystem metabolism and atmospheric $\mathrm{CO}_{2}$ flux in the northern South China Sea. Deep-Sea Research. Part I, Oceanographic Research Papers, 157, 103205. https://doi.org/10.1016/j.dsr.2019.103205

Jankowski, K, J., Mejia, F, H., Blaszczak, J, R., \& Holtgrieve, G, W. (2021). Aquatic ecosystem metabolism as a tool in environmental management. Wiley Interdisciplinary Reviews: Water, (1), 1-27. https://doi.org/10.1002/wat2.1521

Jauhiainen, J., Kerojoki, O., Silvennoinen, H., Limin, S., \& Vasander, H. (2014). Heterotrophic respiration in drained tropical peat is greatly affected by temperature-a passive ecosystem cooling experiment. Environmental Research Letters, 9(10), 105013-. https://doi.org/10.1088/1748-9326/9/10/105013

Jin, H, S., White, D, S., Ramsey, J, B., \& Kipphut, G, W. (2012). Mixed Tracer Injection Method to Measure Reaeration Coefficients in Small Streams. Water, Air, and Soil Pollution, 223(8), 5297-5306. https://doi.org/10.1007/s11270-012-1280-8

Kaushal, S, S., McDowell, W, H., \& Wollheim, W, M. (2014). Tracking evolution of urban biogeochemical cycles: past, present, and future. Biogeochemistry, 121(1), 1-21. https://doi.org/10.1007/s10533-0140014-y

Lavelle, A. (2018). Stream ecosystem responses to restoration across urban tributaries of the River Thames, London. Ph.D. thesis. King's College London, United Kingdom, London.

Lavelle, A., Bury, N, R., O’Shea, F, T., \& Chadwick, M, A. (2019). Influence of urban river restoration on nitrogen dynamics at the sediment-water interface. PloS One, 14(3). p. e0212690. https://doi.org/10.1371/journal.pone.0212690

Levi, P., \& McIntyre, P. (2020). Ecosystem responses to channel restoration decline with stream size in urban river networks. Ecological Applications p.e02107. 

restoration measures? Ecological Engineering, 61, 174-181. https://doi.org/10.1016/j.ecoleng.2013.09.027

Manning, D. P., Rosemond, A. D., Gulis, V., Benstead, J. P., \& Kominoski, J. S. (2018). Nutrients and temperature additively increase stream microbial respiration. Global Change Biology, 24(1), 233-247. https://doi.org/10.1111/gcb.13906

Meyer, J, L., Paul, M, J., \& Taulbee, W, K. (2005). Stream ecosystem function in urbanizing landscapes. Journal of the North American Benthological Society, 24(3), 602-612. https://doi.org/10.1899/04021.1

Millier, H, K., Hooda, P, S., \& Downward, S, R. (2010). The impact of treated sewage wastewater discharges on the phosphorus levels and hydrology of two second order rivers flowing into the Thames. Journal of Environmental Monitoring, 12(6), 1307-1314. https://doi.org/10.1039/b923263j

Mulholland, P, J., Helon, A, M., Dodds, W, K., Findlay, S, G., Gergogy, S, V., Grimm, N, B., Johnson, S, L., Mcdowell, W, H., Meyer, J, L., Valett H, M., Webster, J, R., Arango, C, P., Poole, G, C., Beaulieu, J, J.,

Nifong, R, L., Taylor, J, M., \& Yasarer, L. (2020). To model or measure: Estimating gas exchange to measure metabolism in shallow, low-gradient stream habitats. Freshwater Science, 39(1), 70-85. https://doi.org/10.1086/707460

Noormets, A. (2009). Phenology of ecosystem processes: Applications in global change research. Springer New York. https://doi.org/10.1007/978-1-4419-0026-5

Omole, D, O., Longe, E, O., \& Musa, A, G. (2013). An approach to reaeration coefficient modeling in local surface water quality monitoring. Environmental Modeling \& Assessment, 18(1), 85-94. https://doi.org/10.1007/s10666-012-9328-0 Woodward, G. (2012). Consistent temperature dependence of respiration across ecosystems contrasting in thermal history. Global Change Biology, 18(4), 1300-1311. https://doi.org/10.1111/j.13652486.2011.02597.x 
Pollock, M, S., Clarke, M, J., \& Dubé, M, G. (2007). The effects of hypoxia on fishes: From ecological relevance to physiological effects. Environmental Reviews, 15, 1-14. https://doi.org/10.1139/a06-006

Pretty, J, L., Harrison, S, C., Shepherd, D, J., Smith, C., Hildrew, A, G., \& Hey, R, D. (2003). River rehabilitation and fish populations: Assessing the benefit of instream structures. The Journal of Applied Ecology, 40(2), 251-265. https://doi.org/10.1046/j.1365-2664.2003.00808.x

Raymond, A. P., Zappa, J, C., Butman, D., Bott, L, T., Potter, J., Mulholland, P., Laursen, E, A., McDowell, H, W., \& Newbold, D. (2012). Scaling the gas transfer velocity and hydraulic geometry in streams and small rivers. Limnology and Oceanography: Fluids and Environments, 2(1), 41-53. https://doi.org/ $10.1215 / 21573689-1597669$

Raymond, P, A., Hartmann, J., Kortelainen, P., Durr, H., Meybeck, M., Ciais, P., Guth, P., Lauerwald, R., Sobek, S., McDonald, C., Hoover, M., Butman, D., Striegl, R., Mayorga, E., \& Humborg, C. (2013).

Reid, A, J., Carlson, A, K., Creed, I, F., Eliason, E, J., Gell, P, A., Johnson, P, J., Kidd, K, A., MacCormack, T, J., Olden, J, D., Ormerod, S, J., Smol, J, P., Taylor, W, W., Tockner, K., Vermaire, J, C., Dudgeon, D., \& Cooke, S, J. (2019). Emerging threats and persistent conservation challenges for freshwater biodiversity. Biological Reviews of the Cambridge Philosophical Society, 94(3), 849-873. https://doi.org/10.1111/brv.12480

Reisinger, J, A., Doody, R, T., Groffman, M, P., Kaushal, S, S., \& Rosi, J, E. (2019). Seeing the light: urban stream restoration affects stream metabolism and nitrate uptake via changes in canopy cover. Ecological Applications, 29, p.e01941. https://doi.org/10.1002/eap.1941

River Restoration Centre (2012). River Pool Linear Park Enhancement Project, Lewisham.

River Wandle Catchment Plan (2014). Available at: http://www.wandle.trust.org

Roberts, B, J., Mulholland, P, J., \& Hill, W, R. (2007). Multiple scales of temporal variability in ecosystem metabolism rates: Results from 2 years of continuous monitoring in a forested headwater stream. Ecosystems, 10(4), 588-606. https://doi.org/10.1007/s10021-007-9059-2 Sensors in the stream: The high-frequency wave of the present. Environmental Science \& Technology, 50(19), 10297-10307. https://doi.org/10.1021/acs.est.6b02155 

metabolism to entire river networks. Ecosystems, 22(4), 892-911. https://doi.org/10.1007/s10021-018$0311-8$

Schnell, S., Bawa-Allah, K., Otitoloju, A., Hogstrand, C., Miller, T, H., Barron, L, P., \& Bury, N, R. (2015). Environmental monitoring of urban streams using a primary fish gill cell culture system (FIGCS). Ecotoxicology and Environmental Safety, 120, 279-285. https://doi.org/10.1016/j.ecoenv.2015.06.012

Smith, B., \& Chadwick, M. (2014). Litter decomposition in highly urbanized rivers: influence of restoration on ecosystem function. Fundamental \& Applied Limnology, 185, 7-18. https://doi.org/10.1127/fal/2014/0581

Soares, P, A., Faht, G., Pinheiro, A., da Silva, M, R., \& Zucco, E. (2013). Determination of reaeration-rate coefficient by modified tracer gas technique. Hydrological Processes, 27(19), 2710-2720. https://doi.org/10.1002/hyp.9371

603

South East Rivers Trust (2010). Butter Hill Phase 1 River Wandle, Carshalton: Thames Water, Environment Agency, Wild Trout Trust.

605

South East Rivers Trust (2013). Bourne Hall Weirs River Hogsmill, Ewell: Defra

606

607

Strayer, D, L., \& Dudgeon, D. (2010). Freshwater biodiversity conservation: recent progress and future

Tan, X., Hou, E., Zhang, Q., \& Bunn, S. E. (2021). Benthic metabolism responses to environmental attributes at multiple scales and its linkage to algal community structure in streams. Hydrobiologia, 848(21), 50675085. https://doi.org/10.1007/s10750-021-04693-9

Tank, J, L., \& Dodds, W, K. (2003). Nutrient limitation of epilithic and epixylic biofilms in ten North American streams: Nutrient limitation on epilithic versus epixylic biofilms. Freshwater Biology, 48(6), 10311049. https://doi.org/10.1046/j.1365-2427.2003.01067.x allochthonous organic matter dynamics and metabolism in streams. Journal of the North American Benthological Society, 29(1), 118-146. https://doi.org/10.1899/08-170.1 
620 Wondzell, S, M., Diabat, M., \& Haggerty, R. (2019). What matters most: are future stream temperatures more sensitive to changing air temperatures, discharge, or riparian vegetation? JAWRA Journal of the American Water Resources Association, 55(1), pp.116-132. https://doi.org/10.1111/1752-1688.12707

Woodward, G., Gessner, M, O., Dobson, M., Elosegi, A., Ferreira, V., Graca, M, S., Fleituch, T., Lacoursiere, J, O., Nistorescu, M., Pozo, J., Risnoveanu, G., Schindler, M., Giller, P, S., Vadineanu, A., Vought, L, M., Chauvet, E., Gulis, V., Hladyz, S., Lecerf, A., \& Carlss, H. (2012). Continental-scale effects of

Yan, J., Liu, J., You, X., Shi, X., \& Zhang, L. (2018). Simulating the gross primary production and ecosystem respiration of estuarine ecosystem in North China with AQUATOX. Ecological Modelling, 373, 1-12. https://doi.org/10.1016/j.ecolmodel.2018.02.004

Young, R, G., Matthaei, C, D., \& Townsend, C, R. (2008). Organic matter breakdown and ecosystem Benthological Society, 27(3), 605-625. https://doi.org/10.1899/07-121.1

Yvon-Durocher, J, I., Trimmer, M., Woodward, G., \& Montoya, J, M. (2010). Warming alters the metabolic balance of ecosystems. Philosophical Transactions. Biological Sciences, 365(1549), 2117-2126. https://doi.org/10.1098/rstb.2010.0038 
Table S1. SEM estimations. $\mathrm{SE}=$ standard error; $\mathrm{CR}=$ critical ratio.

\begin{tabular}{llll}
\hline Variables & SE & CR & $\boldsymbol{p}$ value \\
\hline $\mathrm{NO}_{3}{ }^{-} \leftarrow \mathrm{NO}_{3}{ }^{-}$in the effluent & 0.215 & 3.139 & 0.002 \\
$\mathrm{NH}_{4}{ }^{+} \leftarrow \mathrm{NH}_{4}{ }^{+}$in the effluent & 0.304 & 6.020 & 0.001 \\
$\mathrm{PO}_{4}{ }^{3-} \leftarrow \mathrm{PO}_{4}{ }^{3-}$ in the effluent & 0.033 & 22.640 & 0.001 \\
DOC $\leftarrow \mathrm{DOC}^{-}$in the effluent & 0.039 & 12.848 & 0.001 \\
Bioactivity $\leftarrow \mathrm{NH}_{4}{ }^{-}$ & 2.005 & 26.806 & 0.001 \\
Bioactivity $\leftarrow \mathrm{PO}_{4}{ }^{3-}$ & 0.979 & -11.283 & 0.001 \\
Bioactivity $\leftarrow \mathrm{NO}_{3}{ }^{-}$ & 0.078 & 26.795 & 0.001 \\
Bioactivity $\leftarrow \mathrm{DOC}_{\text {Bioactivity } \leftarrow \text { Temperature }}$ & 0.472 & 0.744 & 0.450 \\
ER $\leftarrow$ Bioactivity & 0.017 & 2.176 & 0.004 \\
GPP $\leftarrow \mathrm{PAR}$ & 0.002 & 1.991 & 0.004 \\
GPP $\leftarrow$ Bioactivity & 0.001 & 4.182 & 0.001 \\
Reaeration $\leftarrow$ GPP & 0.571 & 0.487 & 0.626 \\
Reaeration $\leftarrow$ ER & 0.322 & 2.206 & 0.042 \\
Reaeration $\leftarrow$ Decomposition & 0.039 & 2.308 & 0.003 \\
Reaeration $\leftarrow$ Temperature & 1.302 & 0.262 & 0.794 \\
DOC $\leftarrow$ Decomposition & 0.178 & 0.447 & 0.665 \\
Decomposition $\leftarrow$ Bioactivity & 0.006 & 5.693 & 0.001 \\
\hline
\end{tabular}

652

653

654

655

656

657

658

Table S2. SEM fitting indexes

\begin{tabular}{|c|c|c|c|c|}
\hline NPAR & CMIN & DF & $\boldsymbol{p}$ & CMIN/DF \\
\hline 46 & 189.362 & 73 & 0.055 & 2.594 \\
\hline RMR & GFI & AGFI & PGFI & \\
\hline 0.024 & 0.957 & 0.954 & 0.745 & \\
\hline
\end{tabular}

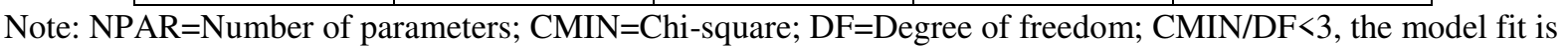
good; RMR=Root mean square of residual, good model fit with the value $<0.05$; GFI=Goodness of fit index, the rage is $0-1$, with the best fit at 1 ; AGFI=Adjusted goodness of fit index, the range is $0-1$, with the good fit at least 0.9; PGFI=Plain goodness of fit index, the range is $0-1$, with the good fit at least 0.5 . 